\title{
Development of Educational Abilities of Students in the System of Continuing Education in the Context of the Pandemic
}

\author{
Dmitry Legenchuk ${ }^{1 *}$
}

\author{
${ }^{1}$ Kurgan State University, Russia \\ *Email: doc600@mail.ru
}

\begin{abstract}
The definition of abilities and their proper development are the most important pedagogical tasks that require special attention, solutions, and approach, especially during the period of changes in the content of the educational process associated with the pandemic. To update the educational approaches associated with remote forms of learning, it is necessary to pay attention to the pedagogical conditions: it is to them that the planned and systematic activity of all participants in the educational process, regardless of the form of its organisation, is subordinated. The article examines the pedagogical conditions that contribute to the development of school students' visual abilities in the context of modernisation and reform of modern Russian education in the context of changes caused by COVID-19. The author analyses the pedagogical conditions to expand the content of the concept of continuity of secondary vocational and higher education developed by him, including in its structure the content components of general education and training of future designers and teachers of technology and design in the structure of multi-level vocational education as potential directions of its development in the context of global challenges associated with changing its tasks and content.
\end{abstract}

Keywords: Concept, Model, Educational activity, Object, Pandemic, Pedagogical conditions, Continuity, System, Remote learning, Educational and cognitive activity, Educational conditions.

\section{INTRODUCTION}

Determination of abilities and their proper development are the most important pedagogical tasks requiring special attention, solutions, and approaches. This is especially relevant, in our opinion, in the process of building multi-level educational complexes based on continuity. Still, the challenge posed to humanity by the pandemic forms a new list of tasks for all levels of the educational activity [2].

Currently, educational institutions worldwide are taking measures to organise the educational process in the coronavirus pandemic context (COVID-19). The forced transition to teaching with the use of distance learning technologies, which took place in the spring of 2020 , forms a request to assess the readiness of students, families and educational organisations of the SPE system to acquire knowledge in new conditions.
The education system had to face unexpected difficulties due to introducing a self-isolation regime and the inability to receive educational services. The closure of educational institutions and the emergency transition to distance learning are associated with problems caused mainly by insufficient technical equipment, lack of teachers and students' inadequate training to work in the new environment. These and other difficulties challenge the education system in this critical situation. Simultaneously, along with apparent challenges and problems, the new training format provides a wide range of opportunities and prospects for changing and improving educational systems for which the critical situation creates forced conditions.

Due to the coronavirus pandemic, Russian educational institutions - universities, colleges and schools - have temporarily switched to distance learning. Most of the additional education institutions have completely stopped working, especially sports 
sections and art schools. State examinations and theses defence in most universities were also held remotely, in music schools and art schools, in most cases, the final certification was carried out according to the current estimates of the last year of study. In the new academic year, which began on September 1, Russian students and schoolchildren started to study in a full-time format. Still, due to the coronavirus pandemic, the educational process is organised with restrictions, and this also affected those educational institutions in which we conducted experimental work on building the process of continuous professional education. We are faced with the reality of creating cross-cutting educational programs based on continuity with the inclusion of elements of distance education and the creation of author's courses of academic disciplines that would replace traditional forms of education with distance education [4].

Let's define the concept of "distance learning". Based on the analysis of the pedagogical literature, we formulate the following definition: distance learning is understood as the organisation of educational activities with the use of distance educational technologies, involving the use of information and telecommunications infrastructure for the transmission of information and indirect synchronous or asynchronous interaction of students and teachers [1]. In our case, this is the process of education based on cross-cutting educational programs within a multi-level educational complex, based on a college and university with the inclusion of additional education institutions in the specialities "Design" and "Teacher of Arts".

We developed and implemented the Concept of Continuity of secondary vocational and higher education, during the implementation of which it became clear that it was necessary to involve general education institutions in a multi-level complex, and the situation associated with the pandemic required an emphasis on distance learning.

Guided by this need, a cross-cutting, continuous trajectory of professional training of technology and design teachers and designers, who are trained by the Kurgan Technological College and Kurgan State University, was built according to integrated educational programs, which quickly included distance learning, author's methods of checking the acquired material were developed, a series of masterclasses on the development of creative and educational abilities of students and students were developed separately by teachers.

However, in implementing the concept, there was a severe problem associated with the low level of development of students' visual abilities, which are the basis of this professional activity. Separately, we want to note that distance learning created additional difficulties in the organisation of this process, in particular, the lack of verbal communication did not allow the teacher and student to maintain interpersonal, trusting nature of communication [3].

As part of high school students' professional orientation, we organised the class-studio "Young Artist" activity to develop visual abilities, based on which training and preparation for training in college and university of future designers and teachers of technology and design took place. Since March 2020, teachers and methodologists have developed special educational technologies for this studio based on a series of author's lecture courses, trainings and masterclasses. Separately, we note that the teaching of all disciplines in the program was fully implemented on the TEAMS platform.

We have identified a range of problems that affect this process. Experimentally, the tasks necessary for developing this group of abilities using distance learning methods are determined. To give results, it is required to pay attention to the pedagogical conditions: it is to them that all participants planned and systematic activity in the educational process is subordinated. In the conditions associated with the actualisation of distance education, the need for a combination of traditional and informational ways of learning comes to the fore.

\section{MATERIALS AND METHODS}

Speaking about the pedagogical conditions that contribute to the development of school students' visual abilities during the pandemic, we adhere to the position that pedagogical conditions are a set of objective possibilities of content, forms, methods, means and material-spatial environment focused on solving the tasks set [2]. Separately, it is worth paying attention to the information environment that needs to be created in an educational institution for access to educational resources, based on educational platforms.

During the study, we introduced two concepts that we defined as fundamental from the point of view of our research:

- "existing conditions" (the state of the educational environment, including information content);

- "newly created conditions" (interaction of two educational environments, in the process of which new conditions appear, including those related to distance education).

Thus, under pedagogical conditions of development of visual abilities we understand the result of the interaction of educational environment of secondary schools and educational environment of additional education of children and the emergence of new conditions - as the last, we introduced:

1. creating an integrated development environment using distance learning; 
2. implementation of the continuous interaction of participants in the process, including on educational platforms, based on remote access;

3. transfer of interaction between organisations of general and additional education of children to the system level of organisation of the process of development of school students' visual abilities, using author's methods that they could study remotely, without reference to the time of study and a specific educational institution [4]

The first condition consists of the following components: objects of reality; the actors perform a variety of artistic activities; the tools, methods, forms of organisation and implementation of the process of development of visual abilities including distance; methodical Association, aimed at engaging teachers of art in secondary schools and teachers of additional education of children's additional education using a remote form of cooperation; development and maintenance of individual educational routes for the development of visual abilities of students with the use of remote educational technologies; integrated authoring program, serving as a model of joint activity of the teacher of the fine arts secondary school, teacher organisations and school children's additional education based on remote educational technologies.

As a result of consistent impact through the environment, the teacher achieves the student's necessary impact. When expanding the boundaries of the educational space using the information educational environment, there is a problem of the interaction quality between the teacher and the student.

The environmental approach's basic concept is "educational environment", and some scientists note its synonymy with the concept of "environmental approach".

Today, there are several interpretations of the concept of "educational environment", and the developing educational environment provides an opportunity for self-development of all subjects of the educational process, regardless of its form. The whole complex of such options, provided by a certain educational environment, is developing potential, speaking about determining the content of the environmental approach's methodological principles as a pedagogical activity [5].

The educational environment has a target function, which consists of forming a person according to a given pattern. Moreover, the objects of practical systemic impact include such elements of the educational environment as the student's immediate school environment, his family environment, the system of additional education institutions, a set of regulatory and program requirements for both students and the teacher's personality.
We consider the environment as a human-created space, which is a condition for the development of abilities, as well as an indicator of professional creativity of specialists since its construction requires imagination from teachers and a variety of ways to create it, this becomes especially relevant in the context of pandemic [6].

Most researchers identify common, typological features of the educational environment. Being in any educational environment, appearing in it or forming it, the same pedagogical and educational systems differently and ambiguously "give out" their characteristics to the pedagogical process. We have recorded this feature in the process of creating distance education programs for a multi-level educational complex, based on continuity, during the pandemic of 2020 [7].

Results and discussions. During a comprehensive analysis of scientific literature, we found that the environment is a potential means of managing personality formation and provides pedagogically appropriate management of the effects of the environment on the student's development. This is extremely important for building the trajectory of his professional development based on continuity. Environmental factors are particularly relevant in times of challenges posed by various global processes to the education system, as was the case during the 2020 pandemic $[8,9]$. Based on the above we can determine that a lot of potential for the disclosure of sufficient abilities and overall creative thinking of schoolchildren have those who were in the adequate to his/her needs educational conditions that can be adjusted remotely by teachers based on and adapted curricula [10].

\section{CONCLUSION}

Modern approaches to the educational process organisation, which are presented in the educational standards, involve creating educational environments aimed at ensuring the development of the interests, abilities and inclinations of schoolchildren. In our study, the interaction of two environments, educational organisations and organisations of additional education, identifies new conditions that impact the development of schoolchildren's visual abilities, including based on remote interaction.

Based on the study, several important points were revealed in the process of implementing distance learning during the coronavirus pandemic:

1. You should not focus on the amount of contact work planned for traditional forms of training, and you should not try to transfer every hour of contact work to an online format. The priority should be the acquisition and assimilation of learning outcomes by students and students with their further assessment and confirmation and not mechanical compliance with classes' schedule. 
2. Theoretical material should be given out in small portions and different forms (audio, video, text) so that students have more opportunities for its assimilation. Particular importance is the author's methods aimed at mastering individual subjects and educational cycles.

3. To consolidate the theoretical material in practical classes, and practice useful skills, online simulators of various formats are needed, developed by teachers based on the course's objectives and content.

4. As studies of the educational distance learning activity shows, satisfaction with learning is the most important, but ambiguous factor in increasing the motivation and effectiveness of learning among students and students [8]. Reduced satisfaction with distance learning negatively affects the effectiveness of the educational process, leading to negative consequences in their mental state: the facts of apathy and depression, deterioration of discipline, absenteeism and absenteeism in contact sessions, the realities of bad attitude associated with aggression and despair, as well as the fear of getting sick COVID-19.

On the other hand, a delighted student with distance learning is an individual focused on independent development, who may not be aware of what is useful for him to learn and what is not due to his age. Such a student has a strong desire for improvement (professional and personal), for this, he does not get up from the computer for days, which subsequently reduces the intensity of motivational energy, worsens interest in the development and effectiveness of his educational activities, and also increases apathy and depression. Thus, the satisfaction with distance learning among students and students should not be maximum, but optimal.

5. The theoretical basis for the interaction of general and additional education in developing students' visual abilities is the concept of educational space, the integrity of the integrated development environment, the selfvalue of general and additional education, supplemented by distance learning.

6. In developing students' visual abilities, continuous interaction is an indissoluble link of a single integrated system of General education and Children's additional education department activities. This system ensures the consistency of each component of the organisation of visual activities (goals, objectives, content, methods, means, forms), which provides the continuous progressive development of these abilities and implements the principle aimed at considering the previous, present and future levels of development of children's visual abilities.

7. The main program and methodological conditions for the continuity of interaction between General education and Children's additional education department in the framework of the development of visual abilities of school students include:
- create an integrated development environment and General education and Children's additional education department promote interaction of all components of the educational space: external (art Museum, exhibition hall, workshops of members of a regional branch of the Union of artists of Russia, non-institution exhibitions and competitions of artworks and their presentation on the web portals) and internal (remote lessons, educational platforms, online plein-air and artworks exhibitions, etc.);

- an integrated program of the class-studio "Young Artist" for the development of visual abilities, which provides a meaningful basis for the cooperation of teachers of General education and teachers of secondary, higher and additional education of Children's additional education department based on distance learning methods;

- conducting joint methodological work of teachers of General education and teachers of secondary, higher and additional education of Children's additional education department based on Internet communities.

8. The effectiveness of the proposed conditions for the interaction of general and additional education of children for the development of visual abilities is ensured:

- creation of the author's concept of the development of students' visual abilities, a model of the process of developing their visual abilities in an integrated environment of General education and Children's additional education department using information technologies;

- expansion of cooperation of teachers of additional education of Children's additional education department and General education teachers in improving content and forms of work on developing students' visual abilities based on remoting.

\section{REFERENCES}

[1] E.V. Romano, T.V. Drozdova, Distance learning: necessary and sufficient conditions for effective implementation, Modern education 1 (2017) 172195. DOI: https://doi.org/10.7256/2409. 8736.2017.1.22044 Retrieved from: https://nbpublish.com/library_read article.php?id= $\underline{22044}$

[2] Zh.R. Nesterova, Pedagogical conditions for developing creative abilities of younger schoolchildren in visual activities through painting, considering federal state requirements. Retrieved from:

https://cyberleninka.ru/article/n/pedagogicheskieusloviya-razvitiya-tvorcheskih-sposobnostey- 
mladshih-shkolnikov-v-izobrazitelnoy-

deyatelnosti-sredstvami-zhivopisi-s

[3] G.G. Shek. Environmental approach as a pedagogical innovation and conditions for its development: Dis. ... Candidate of Pedagogical Sciences: 13.00.01: Yelets, 2001, 148 p. RSL DD, 61:02-13/603-1.

[4] Yu.S. Manuilov, Conceptual foundations of the environmental approach in education. Retrieved from:

https://cyberleninka.ru/article/n/kontseptualnyeosnovy-sredovogo-podhoda-v-vospitanii

[5] V.A. Yasvin, Educational environment: from modelling to design, Moscow: Smysl, 2001, 365 p.

[6] A.V. Ivanov, The phenomenon of the cultural environment of an educational organisation in the development of spiritual values by children. Retrieved from:

https://cyberleninka.ru/article/n/fenomen-

kulturnoy-sredy-obrazovatelnoy-organizatsii-vosvoenii-detmi-duhovnyh-tsennostey

[7] E. Lewandowska, Children's well-being and distance learning during pandemics covid-19, Proceedings of the 5 International Conference on Health and Health Psychology, ICH\&HPSY 2020. Retrieved from: https://www.europeanproceedings.com/files/data/ar ticle/10035/11089/article_10035_11089_pdf_100.p df

[8] D.V. Legenchuk, T.I. Ekimova, Conceptual Foundations for the Development of the Visual Abilities of Applicants Based on Media Competence in the Process of Continuous. Interaction of Educational Organisations. International Scientific Conference "Digitalization of Education: History, Trends and Prospects" (DETP 2020), Published by Atlantis Press SARL. Retrieved from: 2020llhttps://www.atlantispress.com/proceedings/detp-20/125940243

[9] D.V. Legenchuk, Educational and Cognitive Activity in the System of Multilevel Professional Education in the Context of Continuity, Proceedings of the International Scientific and Practical Conference on Education, Health and Human Wellbeing (ICEDER 2019). Retrieved from: https://www.atlantis-press.com/proceedings/iceder$\underline{19 / 125932655}$

[10] D.V. Legenchuk, Peculiarities of Individualization Principles of Multilevel Professional Education Under Conditions of the Cross-Border Educational Complex, Proceedings of the Ecological-SocioEconomic Systems: Models of Competition and
Cooperation (ESES 2019). Retrieved from: https://www.atlantis-press.com/proceedings/eses$\underline{19 / 125931999}$ 